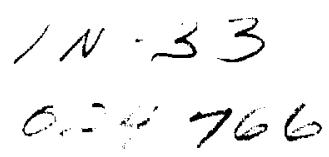

\title{
ELECTRICAL AND THERMAL CHARACTERISTICS OF LITHIUM-ION CELLS
}

Hari Vaidyanathan, COMSAT Laboratories. Clarksburg, MD 20871 USA Gopalakrishna Rao, NASA-Goddard Space flight Center, Greenbelt, MD USA

\begin{abstract}
The 18650 type lithium ion cells are characterized by a cell resistance of $130 \mathrm{~m} \Omega$, capacity of $1.27 \mathrm{Ah}$ at $25^{\circ} \mathrm{C}$. and a mid-discharge voltage of $3.6 \mathrm{~V}$. The capacity loss in the 72-hour stand test was 3.39percent. The heat dissipation properties were determined by a radiative calorimeter. During charge, initial endothermic cooling and subsequent exothermic cooling beyond 55 percent stateof-charge were observed. At $\mathrm{C} / 2$ rate of discharge (which is considered medium rate), the heat dissipated was $17 \mathrm{~mW} / \mathrm{cm}^{3}$. The heat dissipation profile during discharge is also unique in the presence of a minimum that is different from that observed for $\mathrm{Ni}-\mathrm{Cd}, \mathrm{Ni}-\mathrm{MH}$, and $\mathrm{Ni}-\mathrm{H}_{2}$ cells.
\end{abstract}

\section{INTRODUCTION}

The lithium-ion battery was introduced as a commercial product in 1990. It contains a carbon anode and a lithiated metal-oxide cathode in an aprotic solvent. The cathode acts as a source for the lithium ions, which intercalates with carbons such as graphite, petroleum pitch, and hard carbons, on charging and deintercalates from carbon on discharge. The general behavior of the lithium-ion cells, which includes an increase in voltage with increased state-of-charge, increase in self-discharge with temperature, and decrease in capacity with decrease in temperature have been discussed by various authors ${ }^{1,2}$. This study evaluated the electrical and thermal behavior of the lithium-ion cells in order to assess cycle life and the level sophistication required to operate these batteries in satellites, particularly with regard to charge and discharge control and temperature maintenance. The thermal study provides valuable information regarding heat dissipation rates during actual battery operations, dominance of $i^{2} R$ heating, polarization and entropic heat, and parasitic reactions.

\section{CELL SELECTION}

The cells selected for this study were provided to COMSAT Laboratories by NASA/GSFC and they were 18650 - type cylindrical cells. The cells contained spiral wound graphite anodes and $25 \% \mathrm{LiNiO}_{2}-75 \% \mathrm{LiCoO}_{2}$ cathodes in a nickel plated steel case. Each cell weighed $43 \mathrm{~g}$ and had a volume of $16.5 \mathrm{~cm}^{3}$.

\section{CAPACITY AND VOLTAGE}

A constant-temperature chamber was used for capacity determinations. A requirement with respect to maximum and minimum lithium fraction in the 
cathode and anode dictates a voltage maximum of $4.1 \mathrm{~V}$ for charge and a minimum of $2.5 \mathrm{~V}$ during discharge. Another limitation with regard to the maximum rates of charge and discharge arises from the lower conductivity of the electrolyte and slow mass transfer conditions. Figure 1 shows the discharge profiles for the cells at $-4^{\circ} \mathrm{C}, 10^{\circ} \mathrm{C}$. and $25^{\circ} \mathrm{C}$ at the $\mathrm{C} / 5$ rate. Cell capacity increased from $0.98 \mathrm{Ah}$ at $0^{\circ} \mathrm{C}$ to $1.31 \mathrm{Ah}$ at $25^{\circ} \mathrm{C}$, while capacity and middischarge voltage both increased with temperature. Figure 2 shows the variation of voltage profiles at $\mathrm{C} / 10 /, \mathrm{C} / 5$ and $\mathrm{C} / 2$ rates of discharge. The mid-discharge voltage decreased with increase in rate. One notable feature was the slightly lower capacity obtained at the $\mathrm{C} / 10$ rate compared to $\mathrm{C} / 5$ rate. The reason for this behavior is not known with certainty, it could be related to the time-dependent growth of the passive film on the carbon during anodic polarization,or the formation of lithium dendrites at the cathode. This behavior could also be unique to the graphite used for fabrication of the anode. If passivation is the mechanism then the same mechanism should influence the self-discharge behavior. .Bruce et $\mathrm{al}^{3}$ reported no change in capacity when the discharge rate is increased to $\mathrm{C} / 5$ from $\mathrm{C} / 10$. The average capacity and voltage data for the eight cells are summarized in Table 1.

\section{SELF-DISCHARGE}

The capacity remaining in a charged cell after 72 hours in open circuit condition at $25^{\circ} \mathrm{C}$ was measured. For the 8 cells, capacity loss ranged from 2.73 to $3.33 \%$ percent in 3 days. Thus, the average capacity loss was $1 \%$ per day at $25^{\circ} \mathrm{C}$ as a result of self-discharge. Voltage decay during the 72 -hour open circuit stand (plotted in Figure 3 )shows a decline of only $0.1 \%$. Thus the voltage decay during the 72-hour stand is lower than the capacity loss. Therefore cell voltage cannot be directly related self-discharge.

The self-discharge rate of $1 \%$ may be compared to $2 \%$ obtained for $\mathrm{Ni}-\mathrm{Cd}$ cells and $4 \%$ for $\mathrm{Ni}-\mathrm{H}_{2}$ cells.

The self-discharge mechanism could be the reaction of $\mathrm{Li}_{\mathrm{x}} \mathrm{C}_{6}$ with the electrolyte. The reaction products are passive films on the surface of the anode, gases such as propylene and ethylene, and $\mathrm{Li}^{+}$ions in the electrolyte. Unlike aqueous batteries, lithium-ion cells experience no parasitic reactions such as oxygen generation and recombination, except for corrosion of copper substrate. The active material at the cathode is not expected to undergo any lithiation reaction under open-circuit conditions. Thus, the reactivity of electrolyte and anode dominates the self-discharge mechanism.

\section{HEAT DISSIPATION}

. Heat dissipation during discharge, charge, and self-discharge of batteries is an important parameter not only for the safe operation of the battery but also to extend the cycle and calendar life. In addition, it is important to know whether the battery is susceptible to thermal runaway when the rate of heat generation exceeds the rate of heat dissipation. In other thermal conditions the affects the operation of the battery is the development of thermal gradients and hot spots, which greatly accelerates degradation of the electrolyte, anode, cathode, and the separator. The 
thermal characterization of lithium-ion cells is more complex and fraught with difficulties in view of uncertainty regarding the enthalpy values, reaction mechanisms, and side-reactions. The side-reactions which are suspected of contributing to exothermic heating or endothermic cooling are the corrosion of copper; dissolution of lithium nickel-oxide; lithium cobaltoxide; polymerization of the electrolyte; production of gases such as ethylene, propylene,hydrogen, and oxygen; and hydration and formation of carbonates and flourides. Mathematical analysis of heat rates from lithium ion cells has been reported by Chen and W. Evans ${ }^{4}$; calorimetric measurements of heat rates by Hong et al ${ }^{5}$; and thermodynamic calculations by Deiss, et al. ${ }^{6}$ The findings thus far can be summarized as follows. Temperature coefficient of cell open-circuit voltage is -0.4 $\mathrm{mV} / \mathrm{K}$, and the heat dissipation rate during $\mathrm{C} / 2$ discharge is $10 \mathrm{~mW} / \mathrm{cm}^{3}$, thermal runaway does not occur during normal battery operation. Entropic heat is greater than $50 \%$ of the total heat, and increases with increasd rate of discharge. There is a divergence in the calculated and measured values for the open-circuit potential.

The purpose of this study was to determine the heat dissipation rates during charge and discharge, measure the thermal capacity of the cell and calculate the thermoneutral potential as a function of state of charge. The experimental approach was to use radiative calorimeter and perform the measurements under transient conditions. The radiative calorimeter is ideally suited to determining the heat rates of fractional watts because of its high sensitivity, which is $0.002 \mathrm{~W} /{ }^{\circ} \mathrm{C}$ for the radiative term, compared to $1 \mathrm{~W} /{ }^{\circ} \mathrm{C}$ for the calorimetric constant for the conductive calorimeter. Heat leakage through the leads and sensing wires by conduction can be calculated and compensated. The term $\mathrm{mCp} \delta \mathrm{T} / \delta \mathrm{t}$ is involved in the calculations, and heat stored and heat dissipated are calculated separately.

\section{CALORIMETER}

The calorimeter is designed for radiative transfer of heat from the cell its surroundings. ${ }^{7}$ It consists of a $0.5-\mathrm{m}^{3}$ copper chamber that is maintained at $-168^{\circ} \mathrm{C}$ by circulating liquid nitrogen. The inside of the chamber is painted black, and the cell is suspended using a lacing cord. The calorimetric chamber is arranged in bell-jar-type vacuum chamber, and a vacuum of $10^{-5}$ torr is maintained.

In preparing the cell for calorimetry, great care was taken that it had a distinct radiating surface. A $2.54 \mathrm{~cm}$ wide and $5 \mathrm{~cm}$-long thermofoil heater tape was wrapped around the cell and six thermocouples were installed at different areas of the cell. The thermocouple sense wires, terminal leads, voltage sense leads and heater leads were bunched to create two wire bundles and insulated with multiple layers of aluminized Mylar. The exposed areas of the cell were also insulated with multiple layers of aluminized Mylar. Heat was applied to the cell through the thermofoil heaters to raise the cell temperature significantly above that of the 
calorimetric chamber, which is maintained at $-168^{\circ} \mathrm{C}$. Thus, heat is radiated from the cell and follows the relationship:

$\mathrm{Q}_{\mathrm{r}}=\varepsilon \sigma\left(\mathrm{T}_{\mathrm{c}}^{+}-\mathrm{T}_{\mathrm{s}}{ }^{4}\right)$

$\mathrm{Q}_{2}=$ Heat radiated $(\mathrm{W}), \varepsilon=$ emissivity,

$\sigma=$ Stefan-Boltzman constant $3.658 \times 10^{-11} \mathrm{~W} / \mathrm{in}^{2}-\mathrm{K}$,

$\mathrm{T}_{\mathrm{c}}=$ temperature of the cell,

$\mathrm{T}_{\mathrm{s}}=$ temperature of the calorimeter $\left(-168^{\circ} \mathrm{C}\right)$.

Heat dissipated from the cell, $\mathrm{Q}_{\text {diss, }}$ can be expressed as

$\mathrm{Q}_{\text {diss }}=\mathrm{Q}_{\mathrm{h}}-\mathrm{Q}_{\mathrm{r}}-\mathrm{Q}_{\text {cond }} \mathrm{Q}_{\mathrm{s}}$

$\mathrm{Q}_{\mathrm{h}}=$ heater power, $\mathrm{W}$

$\mathrm{Q}_{\mathrm{r}}=$ heat radiated, $\mathrm{W}$

$\mathrm{Q}_{\text {cond }}=$ Conductive heat loss, $\mathrm{W}$

$\mathrm{Q}_{\mathrm{s}}=\mathrm{mC}_{\mathrm{p}} \delta \mathrm{T} / \delta \mathrm{tW}$

$\mathrm{m}=$ mass of the cell $(\mathrm{g})$,

$\mathrm{C}_{\mathrm{p}}=$ thermal capacity $\left(\mathrm{J} /{ }^{\circ} \mathrm{C}\right)$ of the cell

$\mathrm{T}=$ temperature of the cell $\left({ }^{\circ} \mathrm{C}\right)$

$\mathrm{T}=$ time (hours)

To allow for heat loss and gain through the voltage sense and power leads, heater power leads and thermocouple leads, the conductive heat transfer from the cell through the leads was calculated by measuring the temperature difference at the beginning ( cell surface) and end (point of exit from the calorimeter) of the wire bundle. Values (in watts) are calculated as follows:

$\mathrm{Q}_{\text {cond }}=\mathrm{hA}\left(\mathrm{T}_{\text {cell }}-\mathrm{T}_{\text {wire bundle }}\right) / 1$

$h=$ heat transfer coefficient of lead and wire materials

$A=$ cross-sectional area, $\mathrm{cm}^{2}$

$\mathrm{L}=$ length of the wires and leads, $\mathrm{cm}$

$\mathrm{T}_{\text {wire bundle }}=$ temperature of the wire bundle, ${ }^{\circ} \mathrm{C}$

$\mathrm{Q}_{\text {cond }}=$ heat transfer by conduction, $\mathrm{W}$.

The calculated $\mathrm{Q}_{\text {cond }}$ was $00.01118 \mathrm{~W} /{ }^{\circ} \mathrm{C}$. The power applied to the cell heater was set at different values, and the corresponding cell temperatures were measured at steady state and at open-circuit voltage. The steady state data were plotted and the following equation was derived:

$\mathrm{Q}_{\mathrm{r}}=1.675 \times 10^{-10}\left(273+\mathrm{T}_{\mathrm{avg}}\right)^{4}$

The thermal capacity the cell was determined based on the temperature transients during warm-up at a heater power of 1.92 Watts and during cool down using no heater power. The average cell temperature was converted to $Q_{\text {radiated }}$ using equation (5) for several time intervals and the $Q_{\text {conductance }}$ was calculated using equation (4). The thermal capacity was then calculated using the following equation: 
The thermal capacity of the cell was $40.246 \mathrm{~J} /{ }^{\circ} \mathrm{C}$, and the normalized value was $0.946 \mathrm{~J} /{ }^{\circ} \mathrm{C}$ gram.

\section{HEAT DISSIPATION DURING CHARGE}

The cell was charged at $250 \mathrm{~mA}$ to $4.1 \mathrm{~V}$ at a heater power of $1.912 \mathrm{~W}$, and the variation of heat rate was determined. Figure 4 shows the voltage and heat rate profiles. The thermal behavior is characterized by an initial rise in the heat rate followed by endothermic cooling at about 25 to $30 \%$ state-of-charge and a leveling off towards the end of charge. The maximum endothermic rate was $0.015 \mathrm{~W}$. At the end of charge, the heat rate was $0.039 \mathrm{~W}$. The temperature curve shown in Figure 5 has an inflection corresponding to endothermic cooling at about $25-30 \%$ state-ofcharge and levels off toward the end of charge.

The charging reactions consist of deintercalation of lithium ions from the graphite anode and intercalation into the lithium nickel-oxide cathode. The entropy change dominates the total heat dissipated during charge at $\mathrm{C} / 5$. The deintercalation is believed to be endothermic. The reactions at the carbon anode are not expected to be of any thermal consequence.

\section{HEAT DISSIPATION DURING DISCHARGE}

The rates of heat dissipation during discharge at different rates are shown in Figure 6. The profiles show an initial increase in the heat rate, followed by a decrease. The initial increase was also reported by Hong et al. ${ }^{5}$ The maximum heat rate during the $\mathrm{C} / 2$ discharge was $0.28 \mathrm{~W}$ or $11.21 \mathrm{~W} / \mathrm{cm}^{3}$, and at $\mathrm{C}$ rate, it was $0.55 \mathrm{~W}$.. A general value of $10 \mathrm{~mW} / \mathrm{cc}$ was reported by Chen et al. ${ }^{4}$.

The most striking feature about the heat dissipation is the initial maximum, followed by a reduction in the heat rate. The expected behavior was a gradual increase in the heat rate as discharge continued, followed by a very rapid rise toward the end of discharge.

The total heat generated in the cell has three components: entropic, ohmic, and electrochemical polarization. The heat rate attributable to electrochemical polarization is expected to be much lower in the beginning of discharge, and to increases gradually. The entropic contribution is a function of the chemical state of the participants in the main cell reaction. Ohmic heating is not expected to exhibit significant change during discharge, and is expected to be lower than the heat due to entropy change. The suggested reason for the initial increase in the heat rate during discharge is entropy-related. The main cell reaction is delithiation at the cathode, which is believed to be exothermic. The structure of $\mathrm{Lix}_{\mathrm{X}} \mathrm{CoO}_{2}$ and $\mathrm{LiNiO}_{2}$ has been studied and they are believed to undergo reversible phase transitions due to switching between trigonal and monoclinic crystal symmetries. ${ }^{8}$ Bernardi, Pamikowski, and Newman ${ }^{9}$ reported that phase changes contribute to the total enthalpy and such changes are included as a separate term besides 
reaction enthalpy and the enthalpy of mixing. The suggested explanation for the initial increase, followed by lowering, in the heat rate curve is the phase change in the cathode active material.

\section{THERMONEUTRAL POTENTIAL}

The heat dissipation data obtained in this study can be used to calculate the thermoneutral potential using the following equations:

$$
E_{H}=Q_{\text {diss }} / I+E_{L}
$$

$\mathrm{E}_{\mathrm{H}}$ is thermo-neutral potential, $\mathrm{I}$ is discharge current and $\mathrm{E}_{\mathrm{L}}$ is Cell voltage during discharge. This equation assumes that the discharge reaction is $100 \%$ efficient; and parasitic reactions are neglected

Figure 7 shows the variation of calculated $E_{H}$ values during charge and discharge. The three curves that show the variation of $E_{H}$ during discharge at $C / 5$, $\mathrm{C} / 2$, and $\mathrm{C}$ have a plateau in the mid-discharge region. The curve obtained during charge at $\mathrm{C} / 5$ shows very stable values for $\mathrm{E}_{\mathrm{H}}$. The calculations suggest an average value of $3.836 \mathrm{~V}$ for $\mathrm{E}_{\mathrm{H}}$ as given in Table 2.

The values obtained in this study for the thermo-neutral potential are in agreement with the negative temperature coefficient for the voltage reported in the literaure. ${ }^{5}$ It can be inferred from the thermoneutral potential that:

- The products of the discharge reaction are more ordered than the reactants.

- Zero heat generation and endothermic cooling occur at some point during charge.

- Battery discharge will generate heat.

- Open circuit potential will be less than thermoneutral potential at all temperatures.

Ordinarily, the thermoneutral potential can be used to calculate heat dissipation during various operating conditions, based on known voltage profiles during charge and discharge. Before values reported in thus study are used, they should confirmed using cells produced under various manufacturing conditions.

\section{CONCLUSIONS}

The experimental data suggest that the capacity of lithium-ion cells increased from $0.98 \mathrm{Ah}$ at $0^{\circ} \mathrm{C}$ to $1.31 \mathrm{Ah}$ at $25^{\circ} \mathrm{C}$. The cells yielded a slightly lower capacity when discharged at $\mathrm{C} / 10$, compared to $\mathrm{C} / 5$, that was contrary to expectations. Self-discharge at $25^{\circ} \mathrm{C}$ in the 72 -hour charged stand test was $1 \%$ per day.

Thermal capacity of the cell was $40.24 \mathrm{~J} /{ }^{\circ} \mathrm{C}$. The heat dissipated during discharge increased with the rate of discharge. During charge, endothermic cooling was obtained initially, followed by exothermic heating beyond $55 \%$ state-of-charge. At $\mathrm{C} / 2$ rate of discharge (which is considered medium rate) the heat dissipated was $11.2 \mathrm{~mW} / \mathrm{cm}^{3}$. The heat dissipation profile during discharge was also characterized by an inflection 
unlike that observed for $\mathrm{Ni}-\mathrm{Cd}$ and $\mathrm{Ni}-\mathrm{H}_{2}$ cells. The inflection, which appears as a reduction in the heat rate, is attributed to phase changes in both $\mathrm{LiCoO}_{2}$ cells.

The experimental values obtained for the heat dissipation at various charge and discharge rates were used to calculate a thermoneutral potential of $3.836 \mathrm{~V}$. This proposed value can explain the endothermic cooling during charge and the negative temperature coefficient for the cell voltage.

1.

\section{REFERENCES}

1. G. Nagasubramanian, R. G. Jungst, D. Ingersoll, and D. H. Doughty, $38^{\text {th }}$ Power Sources Conference, Cherry Hill, New Jersey, June 1998, Proc., p. 493.

2. B.V.Ratnakumar, M. C. Smart, and S. Surampudi, $38^{\text {th }}$ Power Sources Conference, Cherry Hill, New Jersey, June 1998, Proc., p. 503.

3. G. Bruce, A. Schumacher, and L. Marcoux, $38^{\text {th }}$ Power Sources Conference, Cherry Hill, NJ, June 1998, Proc., p 500.

4. Y. Chen and J. W. Evans, J. Electrochem.Soc., 143, 2708, 1996.

5. J-S. Hong, H. Maleki, S. Al Hallaj, L. Redey, and J. R. Selman, J. electrochem. Soc., 145, 1489, 1998.

6. E. Deiss and A. Wokaun, J.-L. Barras and C. Daul, and P. Dufek, J. Electrochem. Soc.,144, 3877,1997.

7. H. Vaidyanathan and W. H. Kelly, Proc. Intersociety Energy Conversion Engineering Conference., San Diego, CA, 1992, Society of Automobile Engineers, Warrendale, PA, Proc., Vol.1, p. 209.

8. M. M. Thackeray, J. Electrochem. Soc., 142, 1995,2838.

9. D. Bernardi, E. Pawlikowski, and J. Newman, J. electrochem. Soc.,132, 1985,5 . 


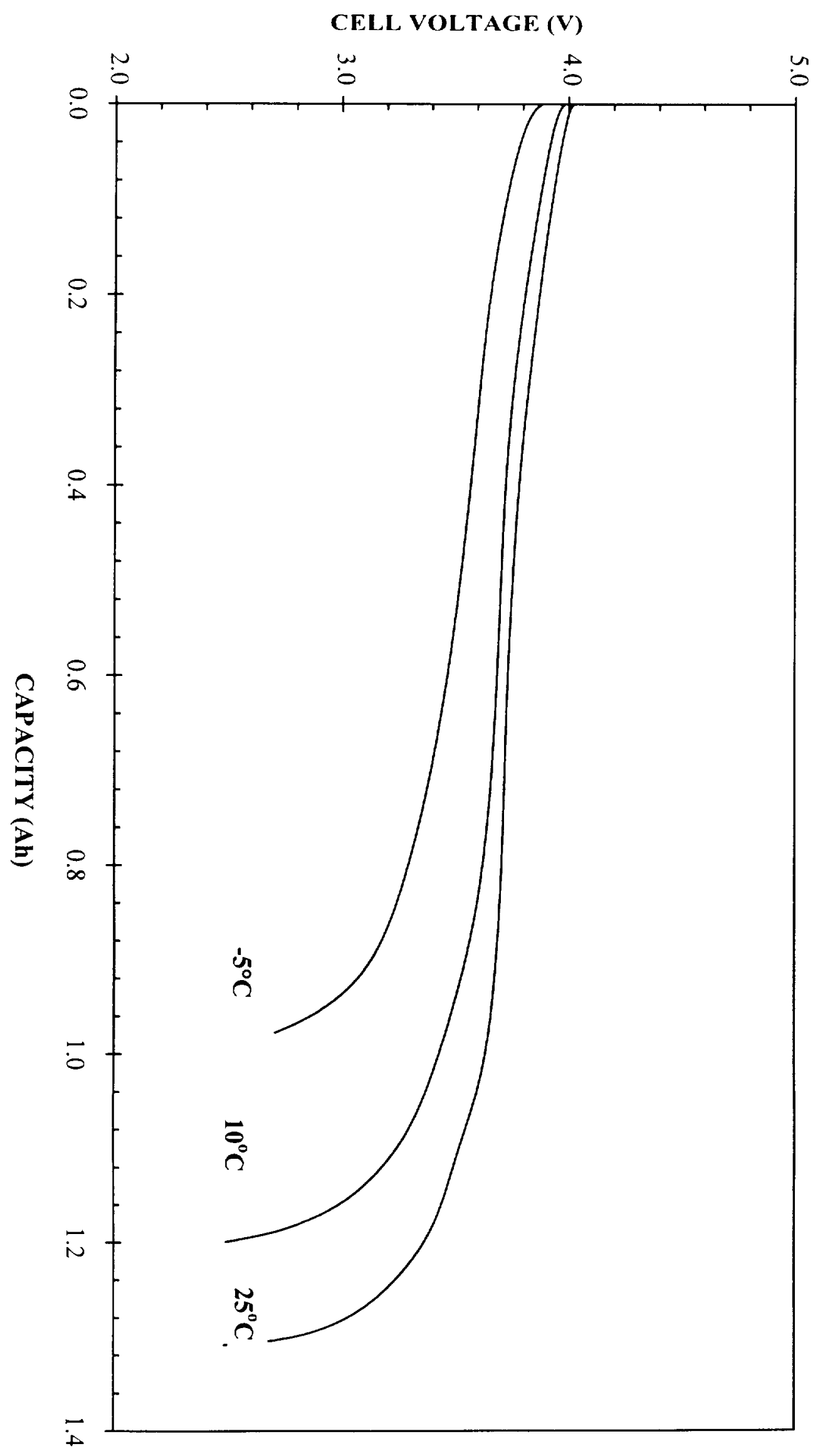

章 


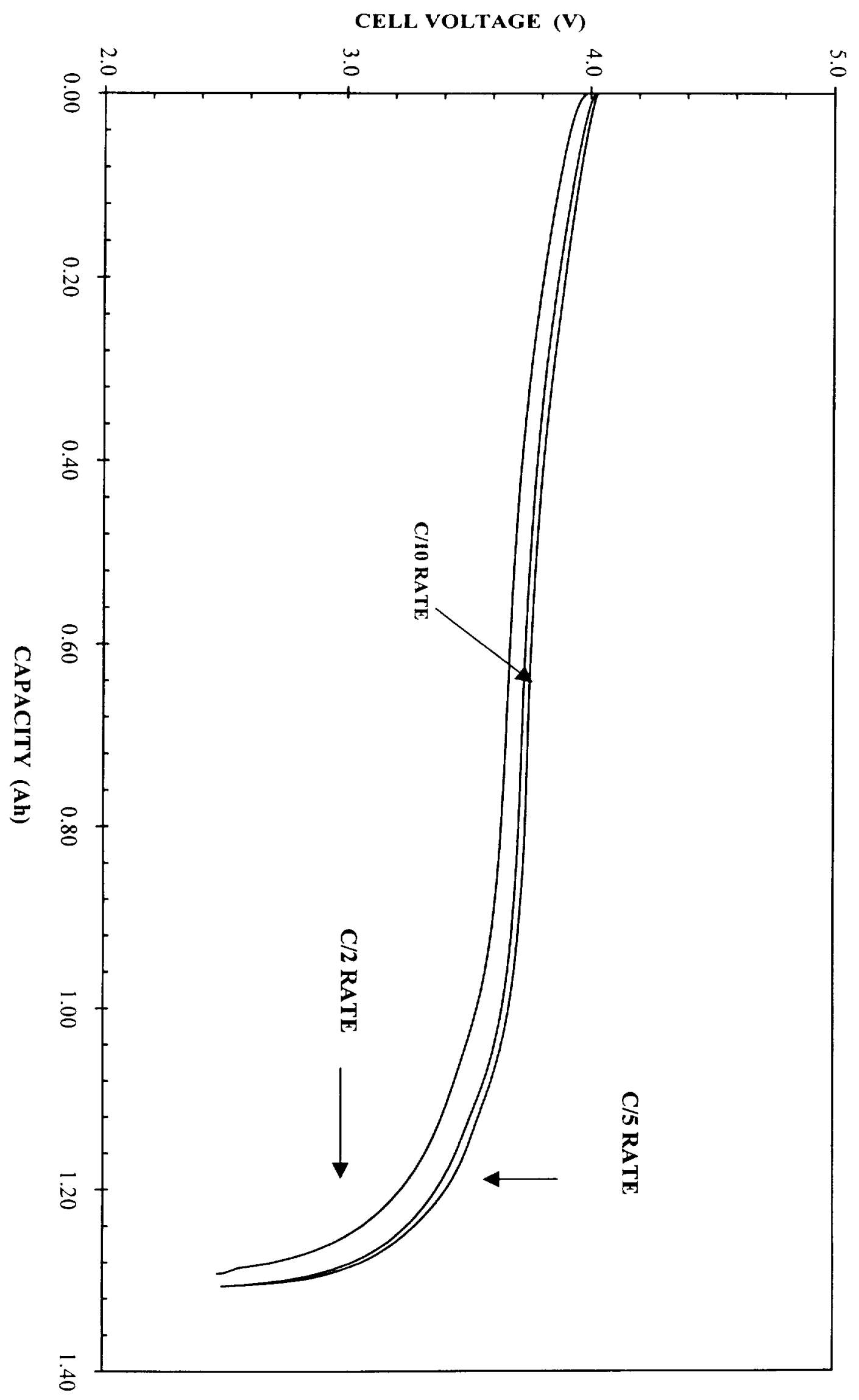

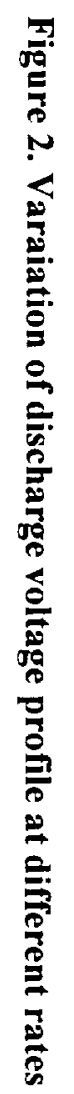




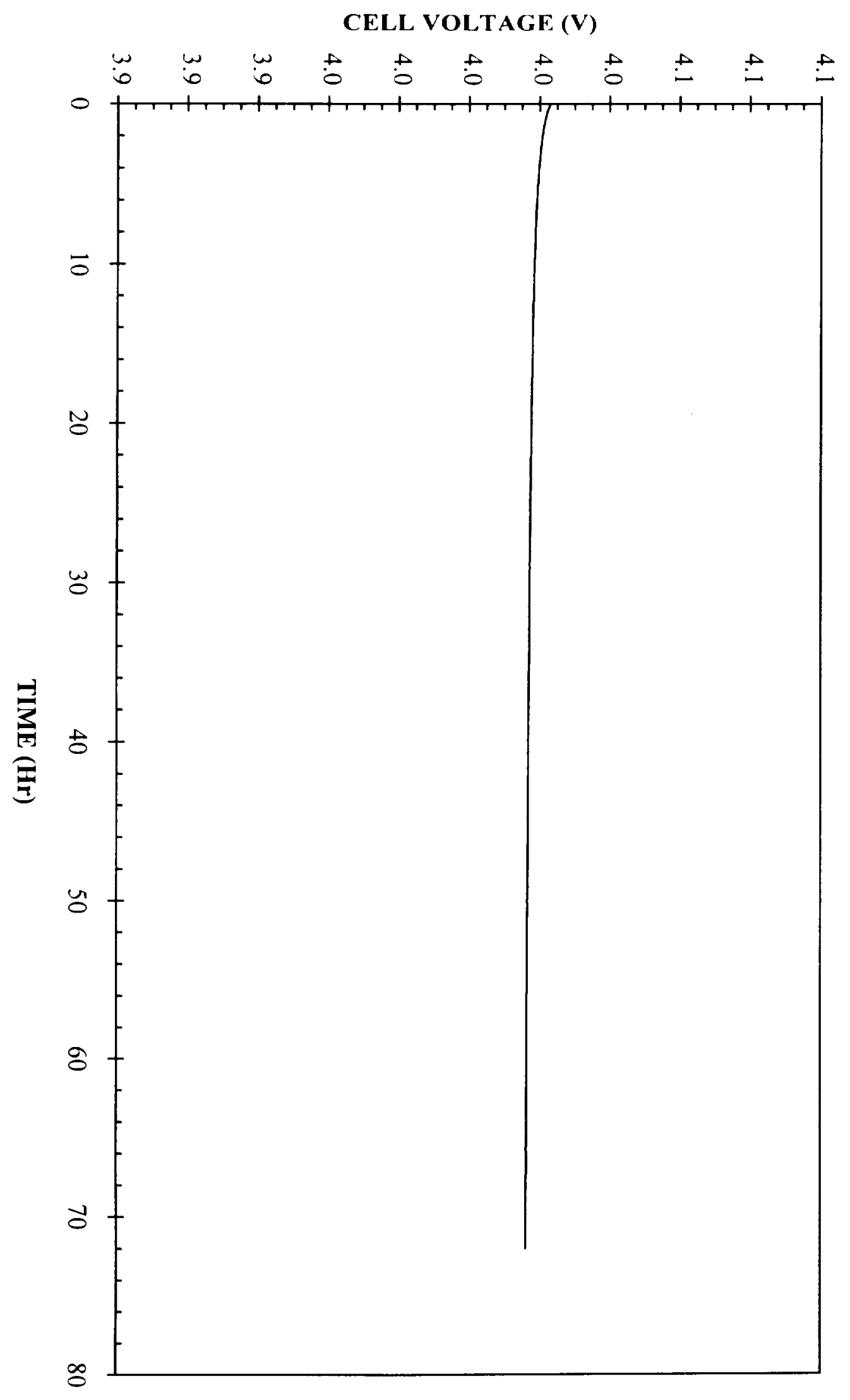

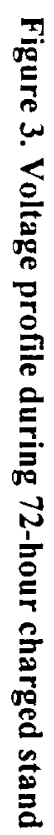




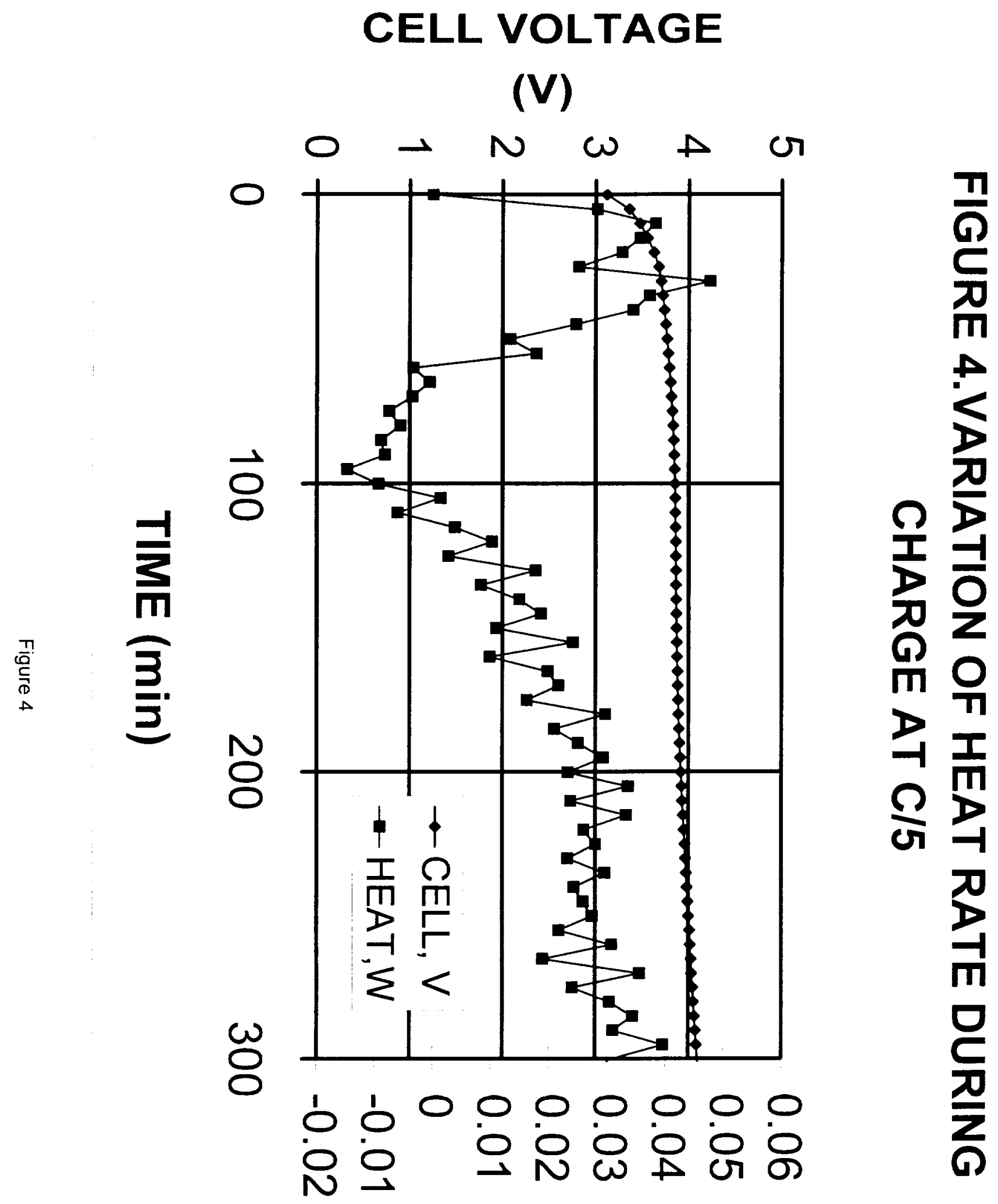

HEAT RATE (W) 


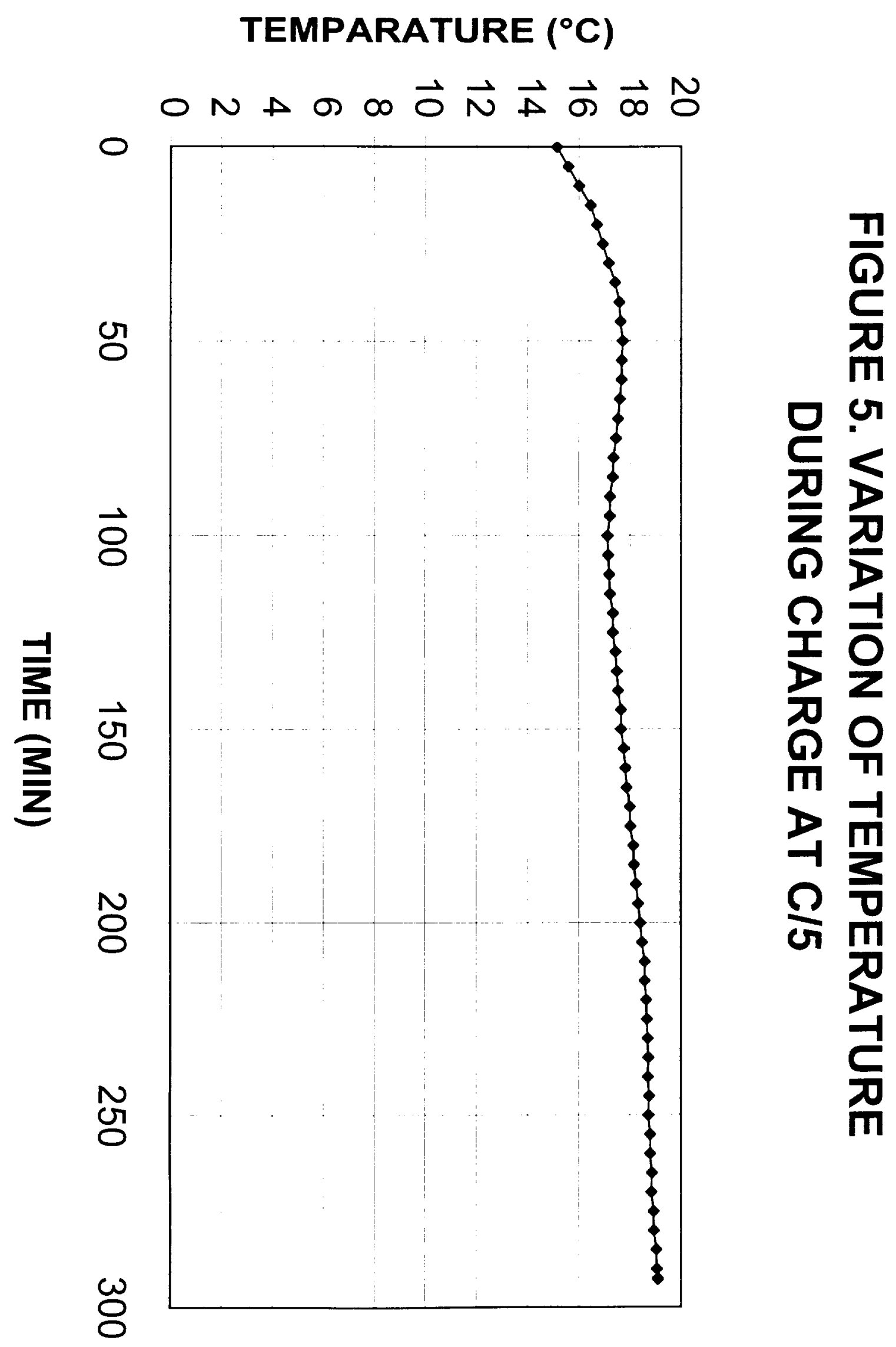



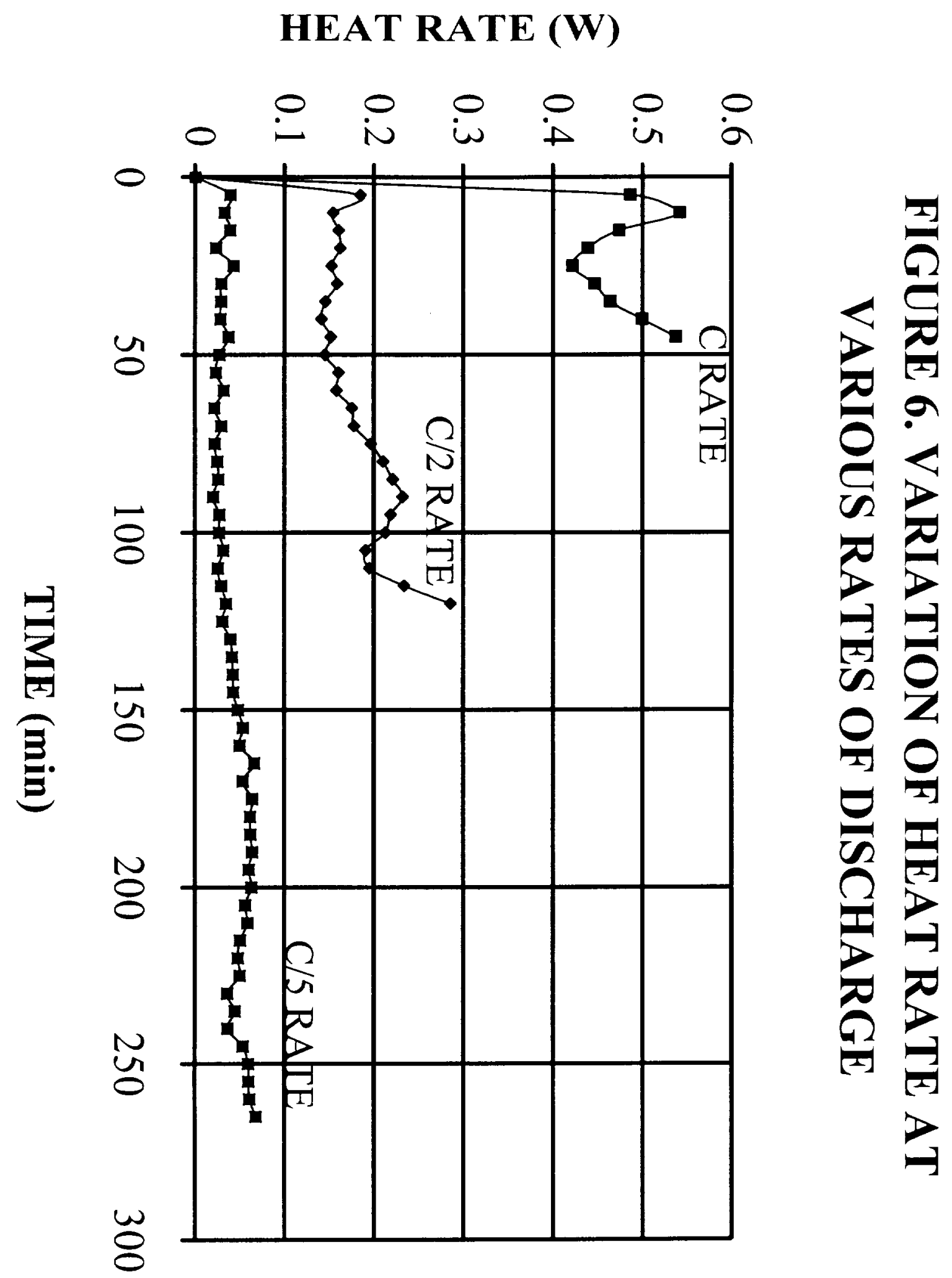
$E_{H}(V)$
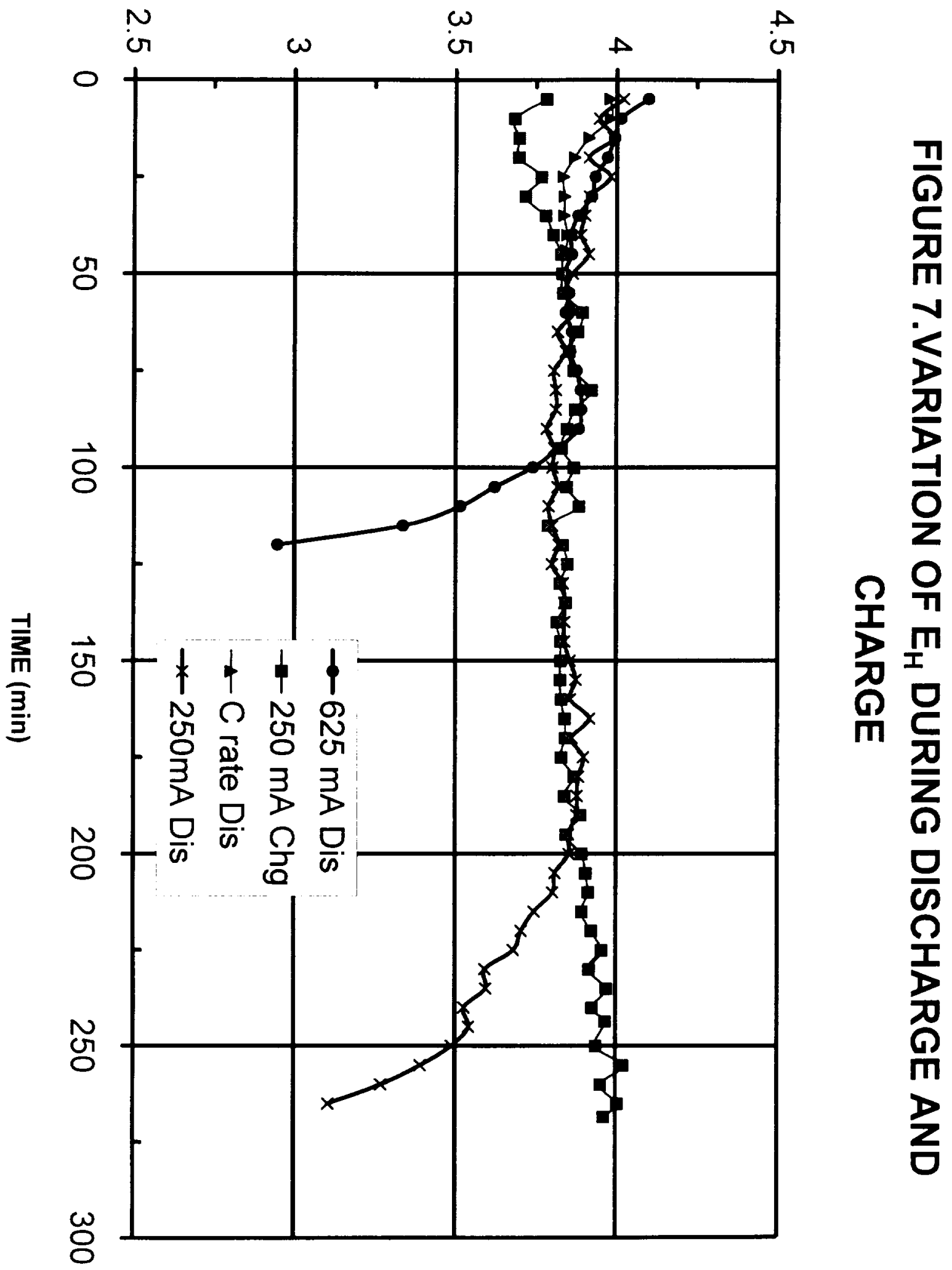


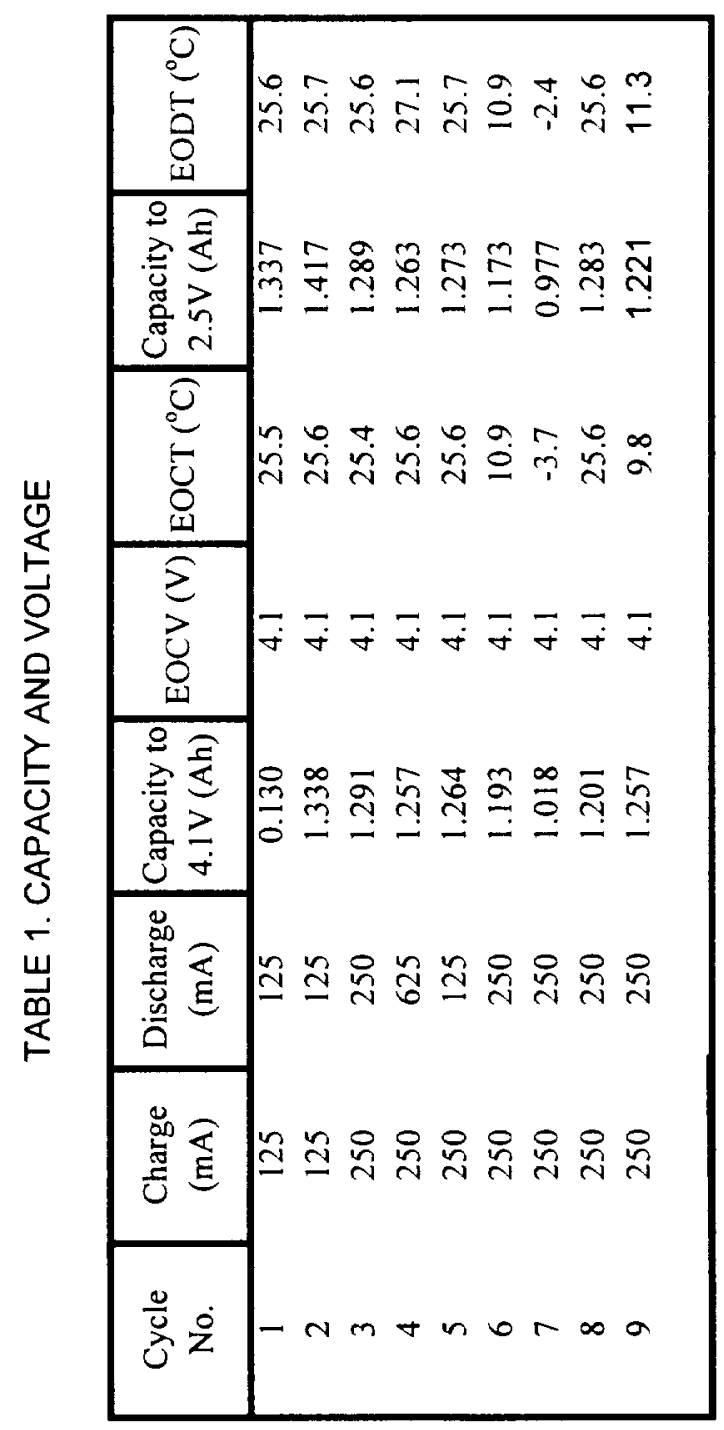




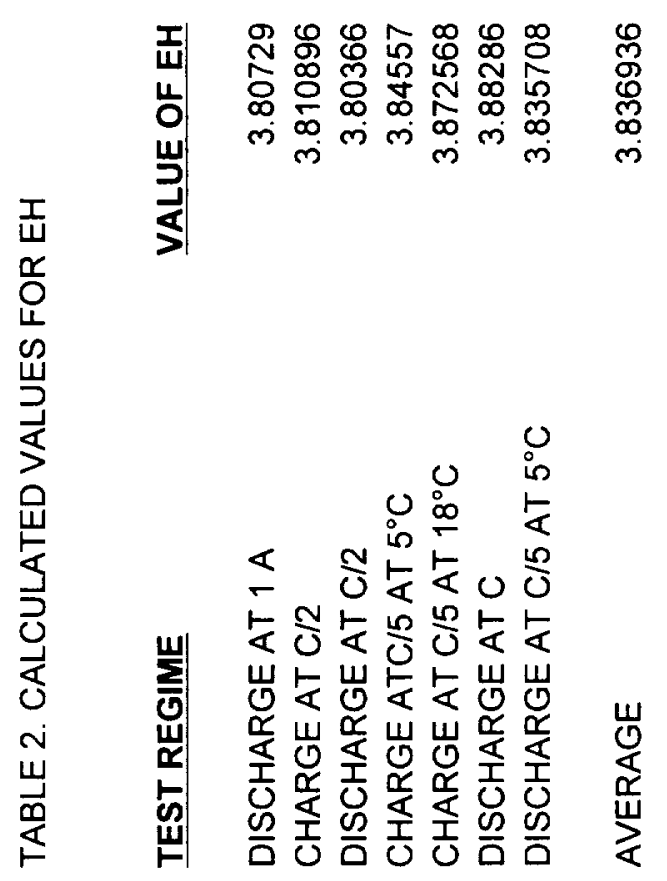

